\title{
A Synchronous Fluorescence Spectrofluorometric Method for the Simultaneous Determination of Clonazepam and Paroxetine Hydrochloride in Combined Pharmaceutical Dose Form
}

\author{
Kombine Farmasötik Illaç Şekillerinde Klonozepam ve Paroksetin \\ Hidroklorür'ün Aynı Anda Belirlenmeleri İçin Senkronize \\ Spektroflorimetrik Yöntem
}

\author{
Jalpa U. PATEL ${ }^{1 *}$, Usmangani K. CHHALOTIYA', Purvi A. SHAH² \\ IIndukaka Ipcowala College of Pharmacy, Gujarat, India \\ ${ }^{2}$ Anand Pharmacy College, Anand, India
}

\begin{abstract}
Objectives: First derivative synchronous spectrofluorimetry has been found to be superior because of its highly specific spectral discrimination and readily available solvent, it is economical, eco-friendly, and lacks an extraction procedure.

Materials and Methods: In the present study, a new simple, sensitive, and time-saving first derivative synchronous spectrofluorimetry method has been developed for simultaneous estimation of clonazepam (CLO) and paroxetine hydrochloride (PH) in pharmaceutical dose forms.

Results: CLO was determined at the emission wavelength of $512.79 \mathrm{~nm}$ (zero-crossing wavelength point of PH). Similarly, PH was measured at $336.00 \mathrm{~nm}$ (zero-crossing wavelength point of CLO). The first derivative amplitude-concentration plots were rectilinear over the range of 1-5 $\mu \mathrm{g} /$ $\mathrm{mL}$ for $\mathrm{CLO}$ and $5-25 \mu \mathrm{g} / \mathrm{mL}$ for $\mathrm{PH}$. The method was validated statistically as per the ICH guidelines. The limits of detection were 0.055 and 0.033 $\mu \mathrm{g} / \mathrm{mL}$ and quantification limits were 0.169 and $0.102 \mu \mathrm{g} / \mathrm{mL}$ for CLO and $\mathrm{PH}$, respectively. The percentage recovery in commercial formulation was found to be in the range $100.45 \%$ and $99.38 \%$ for CLO and $\mathrm{PH}$, respectively, by the proposed method, and percent relative standard deviation values for precision and accuracy studies were found to be less than 2.

Conclusion: This spectrofluorimetry method has been found to have several advantages such as simple spectra, high selectivity, and low interference. By virtue of its high sensitivity, this method could be applied to the analysis of both CLO and PH in their co-formulated dose forms. Key words: First-derivative synchronous spectrofluorimetry, clonazepam, paroxetine hydrochloride
\end{abstract}

Öz

Amaç: Yüksek spesifiklikte spektral ayırıcılığı, kolay bulunan çözücülerin kullanımı, ekonomik ve çevre dostu oluşu ve ekstraksiyona gerek duymaması sebebiyle birinci türev senkron spektroflorimetri yönteminin üstün olduğu bulundu.

Gereç ve Yöntemler: Bu çalıșmada farmasötik preparatlardan klonazepam (CLO) ve paroksetin hidroklorürün (PH) eş zamanlı tayini için basit, hassas ve zamandan tasarruf sağlayan birinci türev senkronize spektroflorimetri yöntemi geliștirilmiştir.

Bulgular: CLO, 512.79 nm'deki (PH'nin sıfır olduğu dalga boyu noktasında) emisyon dalga boyunda tayin edilmiştir. Benzer şekilde PH ise 336.00 nm'deki (CLO'nun sıfır olduğu dalga boyu noktasında) emisyon dalga boyunda ölçüm yapılarak tayin edilmiştir. Birinci türev için pik yüksekliğine karşı çizilen konsantrasyon grafiği CLO için 1-5 $\mathrm{gg} / \mathrm{mL}, \mathrm{PH}$ için $5-25 \mu \mathrm{g} / \mathrm{mL}$ aralığında doğrusal olarak bulunmuştur. Yöntemin istatistiksel validasyonu ICH kılavuzlarına uygun olarak istatistiksel gerçekleştirilmiştir. Teșhis sınırı CLO ve PH için sırasıyla 0.055 ve $0.033 \mu \mathrm{g} / \mathrm{mL}$, tayin sınırı ise 0.169 ve 0.102 $\mu \mathrm{g} / \mathrm{mL}$ 'dir. Önerilen yöntem kullanılarak piyasa preparatlarındaki yüzde geri kazanım sonuçları CLO ve PH için sırasıyla \%100.45 ile \%99.38 arasında ve yüzde bağıl standart sapma değerleri de kesinlik ve doğruluk çalışmalarında 2'den daha düşük bulunmuștur.

Sonuç: Bu spektroflorimetri yönteminin, basit spektrumlar, yüksek seçicilik ve düşük girişim gibi birçok avantajı olduğu bulunmuştur. Yüksek duyarlılığından dolayı, bu yöntem CLO ve PH'nin birlikte formüle edilmiş dozaj formlarından analizi için uygundur.

Anahtar kelimeler: Birinci türev senkronize spektroflorimetri, klonazepam, paroksetin hidroklorür

*Correspondence: E-mail: jalpa.patel70@ymail.com, Phone: +91 9033994032 ORCID-ID: orcid.org/0000-0002-8134-6294

Received: 11.08.2016, Accepted: 08.12.2016

TTurk J Pharm Sci, Published by Galenos Publishing House. 


\section{INTRODUCTION}

The frequent association between panic disorders and depression is extensively documented in both clinical and epidemiologic studies, and it is considered to be more of a common phenomenon than an exception. Current treatment recommendations for comorbid depression and anxiety are based on clinical experience with the treatment of anxiety and depressive disorders when they occur independently. There are studies that have tried combinations of selective serotonin reuptake inhibitors (SSRI) (paroxetine) and benzodiazepine (clonazepam) in patients of depression and anxiety/panic disorders. Hence, the availability of a fixed dose combination of an anti-depressant such as paroxetine hydrochloride $(\mathrm{PH})$ and an anti-anxiety drug such as clonazepam (CLO) would be a useful treatment option for the management of co-morbid depression and anxiety. ${ }^{1-4}$

CLO [5-(2-chlorophenyl)-7-nitro-2, 3-dihydro-1H-1,4benzodiazepin-2-one], Figure 1 is a benzodiazepine drug that has anxiolytic, anticonvulsant, muscle relaxant, sedative, and hypnotic properties. CLO exerts its action by binding to the benzodiazepine site of GABA receptors, which causes an enhancement of the electrical effect of GABA binding on neurons, resulting in an increased influx of chloride ions into the neurons. These result in an inhibition of synaptic transmission across the central nervous system. ${ }^{3-5}$

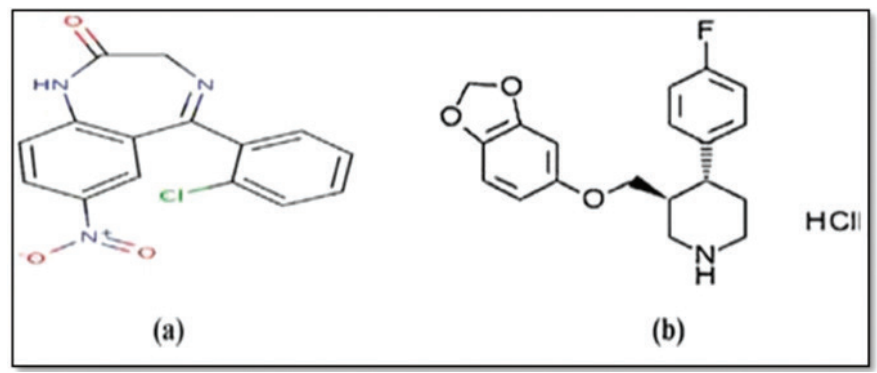

Figure 1. Chemical structure of (a) CLO and (b) PH

PH [(-)-Trans-4R-(4'-fluorophenyl)-3S-[(3', 4'-methylenedioxyphenoxy) methyl] piperidine hydrochloride], Figure $1 \mathrm{~b}$ is an SSRI and potentiates $5-\mathrm{HT}$ in the CNS. PH is indicated for the treatment of major depressive disorder, social anxiety disorder, obsessive-compulsive disorder, panic disorder, generalized anxiety disorder, and post-traumatic stress disorder. It exerts its antidepressant effect through selective inhibition for the reuptake of the neurotransmitter serotonin by presynaptic receptors. ${ }^{3-5}$

CLO and PH both are official drugs in the Indian Pharmacopoeia, United States Pharmacopeia, and British Pharmacopoeia when used individually, but the combination of CLO and $\mathrm{PH}$ is not official in any pharmacopoeia. ${ }^{5-7} \mathrm{CLO}$ and $\mathrm{PH}$ have been formulated in a fixed-dose combination and used in the treatment of depression, anxiety, and comorbidities.

Few analytical methods including spectrophotometry ${ }^{8}$, colorimetry ${ }^{9}$, stability-indicating high-performance liquid chromatography ${ }^{10,11}$ high-performancethinlayer chromatography ${ }^{12}$ and ultra-performance liquid chromatography ${ }^{13}$ have been reported for the simultaneous estimation of CLO and PH in combined pharmaceutical formulations. Chromatographic methods offer a high degree of specificity, yet they require large amounts of high purity organic solvents and generate a large amount of waste. Therefore, there is a need for an alternative to these techniques for the routine quality control analysis of the concerned drug.

To the best of our knowledge, no spectrofluorimetric method has yet been reported for the quantification of CLO and PH in combined formulations. Spectrofluorimetric methods have been found more selective than normal UV-spectroscopy due to the quantification of substance at excitation and emission wavelengths. Derivative spectrofluorimetry provides greater selectivity and spectral discrimination than common spectrofluorimetry. It is a powerful approach for the resolution of one analyte whose peak is hidden by a large overlapping peak of another analyte in multi-component analysis. Synchronous fluorescence spectroscopy has been found to have several advantages such as simple spectra, high selectivity, and low interference. The combination of synchronous scanning spectrofluorimetry with derivative techniques is advantageous in terms of sensitivity, spectral discrimination, and more reliable identification of chemical species in multi component analysis. ${ }^{14,15}$

The goal of the present work was to develop a simple, cost effective, sensitive, and rapid method for the simultaneous determination of CLO and $\mathrm{PH}$ in tablet form through firstderivative synchronous fluorimetry (FDSF) based on their native fluorescence. The emission spectra of CLO and PH overlap, which makes it difficult to analyze and determine their contents by conventional fluorimetry. These problems were minimized by using FDSF.

\section{EXPERIMENTAL}

\section{Materials}

All chemicals and reagents were of analytical grade. The CLO and $\mathrm{PH}$ were obtained as gift samples from Vital Formulation, Anand and Torrent Pharmaceutical, and Ahmedabad, respectively. Pari CR Plus formulation (CLO $0.5 \mathrm{mg}$ and PH 12.5 $\mathrm{mg}$ ) were purchased from local pharmacies. Analytical grade methanol purchased from Merck, Mumbai, was used throughout these experiments.

\section{Apparatus}

Fluorescence spectra and measurements were recorded using a spectroflorophotometer (RF-5301PC series, Shimadzu Corporation, Japan), which allowed high sensitivity analysis based on a unique optical system that involves highly efficient Blazed Holographic Grating as well as low-noise circuitry that includes a digital filter. Spectroflorophotometer equipped with a $150 \mathrm{~W}$ xenon arc lamp and slit widths for both monochromators were set at $10 \mathrm{~nm}$. A $1 \mathrm{~cm}^{2}$ quartz cell was used for all measurements. Spectra and intensities were automatically 
obtained using Shimadzu fluorescence spectroscopy software, RFPC version 2.04.

\section{Preparation of standard solutions}

Standard stock solutions each containing $1000 \mu \mathrm{g} / \mathrm{mL}$ of CLO and $\mathrm{PH}$ were prepared separately in the methanol. Working standard solutions $(100 \mu \mathrm{g} / \mathrm{mL})$ of the mentioned drugs were obtained by dilution of the respective stock solution in methanol. Working solutions were prepared separately by making serial dilutions from the standard solution to obtain concentrations between 1-5 and 5-25 $\mu \mathrm{g} / \mathrm{mL}$ for CLO and PH, respectively, and fluorescence intensity was quantified using a spectroflorophotometer.

\section{Spectrofluorimetric methods}

For spectrofluorimetry, the solutions were scanned between $220 \mathrm{~nm}$ to $800 \mathrm{~nm}$ and emission wavelength was selected based on the maximum fluorescence intensity. The excitation and emission wavelength of both the drugs were found. The synchronous spectra of CLO and PH were obtained by keeping a constant interval between emission and excitation wavelength (i.e $\Delta \lambda=20$ ). The obtained synchronous spectra of both drugs were converted to the $1^{\text {st }}$ derivative spectra by optimizing $\Delta \lambda=20$. The first derivative synchronized spectrum of CLO has zero intensity at $336.00 \mathrm{~nm}$, whereas $\mathrm{PH}$ gives significant derivative response. The derivative spectrum of $\mathrm{PH}$ has zero intensity at $512.79 \mathrm{~nm}$, and CLO gives significant derivative response by maintaining a constant interval $\Delta \lambda=20$. Therefore, $512.79 \mathrm{~nm}$ and $336.00 \mathrm{~nm}$ were chosen for the estimation of CLO and PH, respectively. Different aliquots were transferred for both drugs to $10 \mathrm{~nm}$ volumetric flasks and the volumes were adjusted to the mark with methanol to obtain concentrations of $1-5 \mu \mathrm{g} / \mathrm{mL}$ of $\mathrm{CLO}$ and $5-25 \mu \mathrm{g} / \mathrm{mL} \mathrm{PH}$, respectively. The calibration curves between concentration and fluorescence intensity were plotted and corresponding regression equations were derived.

\section{Method validation}

The proposed methods were validated in accordance with International Council for Harmonisation of Technical Requirements for Registration of Pharmaceuticals for Human Use (ICH) guidelines Q2 (R1) for the evaluation of various parameters: linearity, precision, accuracy, limit of detection, limit of quantification, specificity, and robustness. ${ }^{16}$

\section{Linearity and range}

The linear relationship between concentration and amplitude of both drugs were evaluated over the concentration range expressed in the concentrations range of $1-5 \mu \mathrm{g} / \mathrm{mL}$ for CLO, $5-25 \mu \mathrm{g} / \mathrm{mL}$ was selected for $\mathrm{PH}$. The linearity ranges for the determination of CLO and PH by the proposed methods were repeated five times. Calibration curves were constructed by plotting the analyte intensity against the respective concentration.

\section{$\angle O D$ and $L O Q$}

As per the $\mathrm{ICH}$ guidelines, the limit of detection and quantification of the developed method were calculated from the standard deviation of the response and slope of the calibration curve of each drug using the following formulas:

Limit of detection $=3.3 \times \sigma / \mathrm{S}$

Limit of quantification $=10 \times \sigma / \mathrm{S}$

Where, " $\sigma$ " is standard deviation of response, " $S$ " is Slope of calibration curve.

\section{Precision}

The precision of the developed methods were evaluated by performing intraday precision on the same day and interday precision studies on different days in three replicates. Repeatability and intermediate precision was performed for CLO at $1,3,5 \mu \mathrm{g} / \mathrm{mL}$, and $5,15,25 \mu \mathrm{g} / \mathrm{mL}$ for $\mathrm{PH}$. The percent relative standard deviation (\% RSD) was calculated.

\section{Accuracy}

Accuracy of method was ascertained by performing a recovery study using the standard addition method; a known amount of standard drug was added to preanalyzed samples of CLO and $\mathrm{PH}$ at three concentration levels $(50 \%, 100 \%$, and $150 \%$ ) in triplicate. The percentage recovery and RSD were calculated for each concentration.

\section{Robustness}

Robustness was performed by making deliberate changes in wavelength and different model of UV visible spectrophotometer. $\%$ RSD was calculated.

Applicability of the proposed method for analysis of formulation For the analysis of the marketed formulation, 20 tablets were weighed and finely powdered. From the tablet sample, an amount equivalent to $0.5 \mathrm{mg}$ of CLO and $12.5 \mathrm{mg} \mathrm{PH}$ were accurately weighed and taken into a $100 \mathrm{~mL}$ volumetric flask. About $30 \mathrm{~mL}$ of methanol was added and the mixture was sonicated for 15 min. The mixture was diluted to volume with methanol, mixed well and filtered to obtain the sample stock solution, $5 \mu \mathrm{g} / \mathrm{mL}$ of CLO and $125 \mu \mathrm{g} / \mathrm{mL}$ of PH. The resultant solution was used for the analysis of CLO and for analysis of $\mathrm{PH} ; 1 \mathrm{~mL}$ from the above solution was withdrawn and the volume was made up to $10 \mathrm{~mL}$ to make $12.5 \mu \mathrm{g} / \mathrm{mL}$ for $\mathrm{PH}$. The resultant solutions were then used to estimate both drugs at their particular $\lambda_{\max }$ for both methods. The analysis was repeated in triplicate.

\section{RESULTS AND DISCUSSION}

\section{Synchronous fluorescence spectrofluorimetric method}

Different solvent systems were tested in order to find the best conditions such as solubility, fluorescence activity, stability, and spectral discrimination (clear separation) of both drugs. From the results, it was found that CLO and PH gave comparatively high fluorescence intensity in methanol. CLO exhibited native fluorescence at emission wavelength of $460 \mathrm{~nm}$ after excitation at $258 \mathrm{~nm}$ and similarly $\mathrm{PH}$ exhibited fluorescence at emission wavelength of $545 \mathrm{~nm}$ after excitation at $288 \mathrm{~nm}$ in methanol. It was revealed that the fluorescence spectra of these drugs overlapped considerably. As a result, the conventional spectrofluorimetric method did not permit the simultaneous determination of both drugs. 
The overlapped spectra were resolved by using a first-order derivative synchronous spectrofluorimetric method, which was used to choose the suitable wavelengths that make the estimation proportional to CLO and $\mathrm{PH}$ concentrations with the zero cross over point. It was necessary to record the synchronous spectra of CLO and PH shown in Figure 2 and 3 , corrected for the blank signal. There was large overlap of the spectra; the quantification of CLO and PH through synchronous spectrofluorimetry was not possible. This overlap was highly discriminated by using a first-derivative synchronous spectrofluorimetric method (Figure 4).

The first-derivative synchronized spectrum of CLO has zero intensity at $336.00 \mathrm{~nm}$, whereas $\mathrm{PH}$ gives significant derivative response. The derivative spectrum of $\mathrm{PH}$ has zero intensity at $512.79 \mathrm{~nm}$, whereas CLO gives a significant derivative response by maintaining a constant interval $\Delta \lambda=20$. Therefore, $512.79 \mathrm{~nm}$ and $336.00 \mathrm{~nm}$ were chosen for the estimation of CLO and PH, respectively, in tablet form (Figure 5,6 ).

\section{Method validation}

The validation of the methods was performed according to $\mathrm{ICH}$ recommendations.

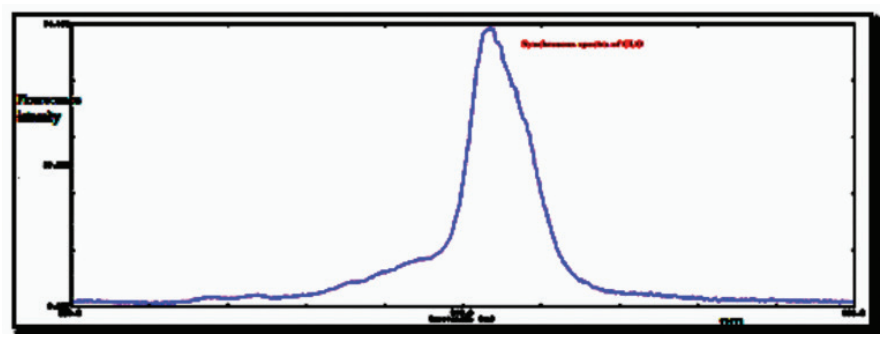

Figure 2. Synchronous spectrum of CLO

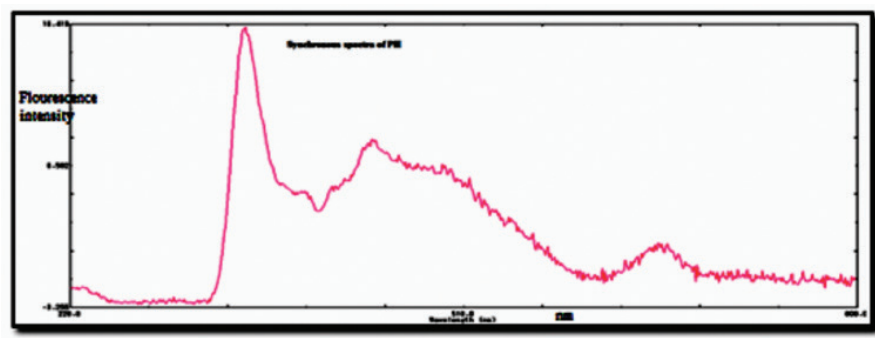

Figure 3. Synchronous spectrum of $\mathrm{PH}$

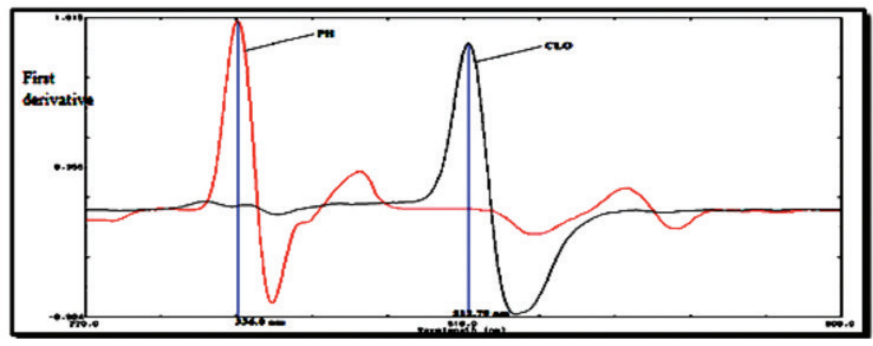

Figure 4. Overlay of $1^{\text {st }}$ order derivative spectrum of CLO and PH

\section{Linearity}

The calibration ranges for CLO and PH were established through considerations of the practical range necessary according to Beer-Lambert's law. Linearity was evaluated using the least square regression method. The responses for CLO were found to be linear in the concentration range of 1-5 $\mu \mathrm{g} / \mathrm{mL}$ with a correlation co-efficient $\left(r^{2}\right)$ value of 0.9986 as depicted in Figure 7. Similarly, the responses for $\mathrm{PH}$ were linear in the concentration range of $5-25 \mu \mathrm{g} / \mathrm{mL}$ with a correlation coefficient $\left(r^{2}\right)$ value of 0.9982 , as shown in Figure 8 . The values of correlation coefficients of CLO and PH were close to unity, indicating good linearity. The characteristic parameters for the constructed equations are summarized in Table 1.

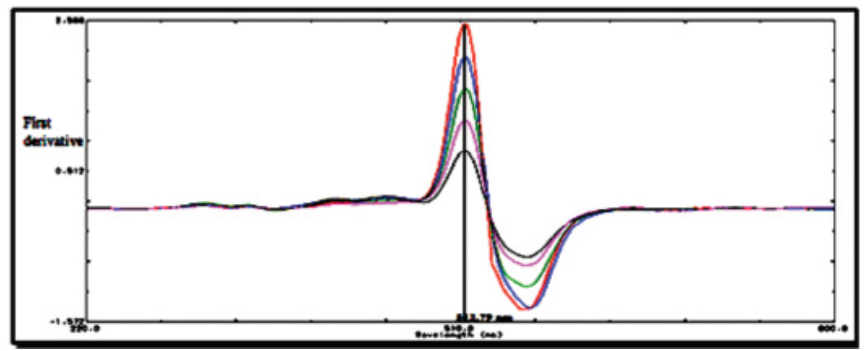

Figure 5. $1^{\text {st }}$ order derivative spectrum of CLO at $512.79 \mathrm{~nm}(1-5 \mu \mathrm{g} / \mathrm{mL})$

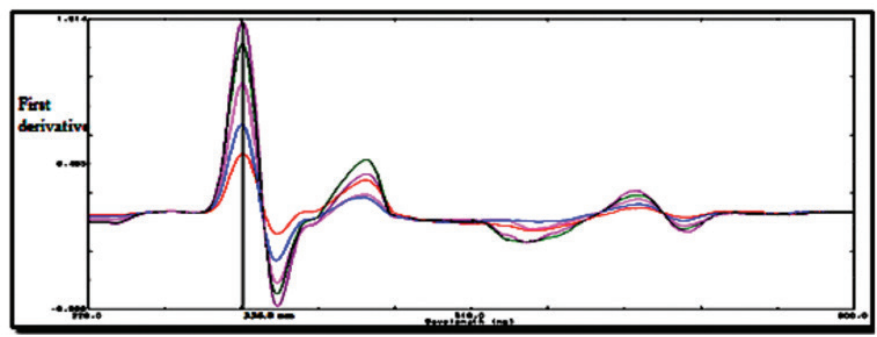

Figure 6. $1^{\text {st }}$ order derivative spectrum of $\mathrm{PH}$ at $336.00 \mathrm{~nm}(1-5 \mu \mathrm{g} / \mathrm{mL})$

Table 1. Linear regression parameters for CLO and PH

\begin{tabular}{lll} 
Parameters & CLO & PH \\
\hline Linearity range $(\mu \mathrm{g} / \mathrm{mL})$ & $1-5$ & $5-25$ \\
\hline Correlation coefficient $\left(\mathrm{r}^{2}\right)$ & 0.9986 & 0.9982 \\
\hline Slope $\pm \mathrm{SD}^{\mathrm{b}}\left(\mathrm{S}_{\mathrm{b}}\right)$ & $0.470 \pm 0.005$ & $0.063 \pm 0.009$ \\
\hline Confidence limit of slope & 0.435 to & 0.058 to \\
\hline Intercept $\pm \mathrm{SD}^{\mathrm{b}}\left(\mathrm{S}_{\mathrm{a}}\right)$ & 0.506 & 0.068 \\
\hline Confidence limit of intercept & 0.156 to 0.392 & 0.006 to 0.169 \\
\hline Limit of detection $(\mu \mathrm{g} / \mathrm{mL})$ & 0.055 & 0.033 \\
\hline Limit of quantification $(\mu \mathrm{g} / \mathrm{mL})$ & 0.169 & 0.102 \\
\hline Bartlett's test ${ }^{\mathrm{b}}\left(\chi^{2}\right)$ & 0.0110 & 0.0054 \\
\hline
\end{tabular}

b: Mean of five determinations, SD: Standard deviation, RSD \%: Relative standard deviation, b $\chi^{2}$ critical value: 9.488 at $\alpha=0.05$, a: Confidence interval at $95 \%$ confidence level and 4 degree of freedom $(t=2.78)$ 


\section{Limit of detection (LOD) and Limit of quantification (LOQ)}

The limit of detection and limit of quantification were determined based on the standard deviation of response ( $y$-intercept) and

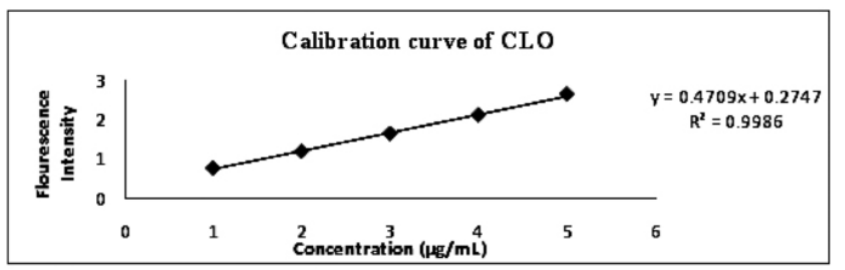

Figure 7. Calibration curve of CLO at $512.79 \mathrm{~nm}$

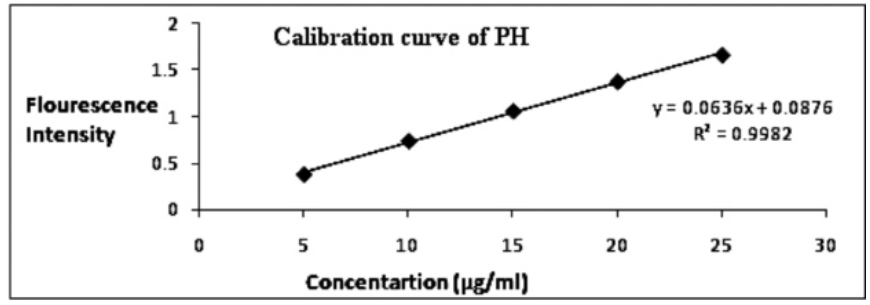

Figure 8. Calibration curve of $\mathrm{PH}$ at $336.00 \mathrm{~nm}$

\section{Table 2. Precision study}

\begin{tabular}{lllll} 
Amount of & \multicolumn{2}{l}{ Intraday precision } & \multicolumn{2}{l}{ Interday precision } \\
\cline { 2 - 5 } drug $(\mu \mathrm{g} / \mathrm{mL})$ & $\begin{array}{l}\text { Amount of drug } \\
\text { found } \pm \text { SD } \\
(\mu \mathrm{g} / \mathrm{mL})\end{array}$ & $\begin{array}{l}\text { RSD \% } \\
\text { found } \pm \text { SD } \\
(\mu \mathrm{g} / \mathrm{mL})\end{array}$ & RSD \% \\
\hline CLO & & & & \\
\hline 1 & $1.056 \pm 0.003$ & 0.454 & $1.069 \pm 0.007$ & 0.946 \\
\hline 3 & $2.899 \pm 0.007$ & 0.473 & $2.956 \pm 0.026$ & 1.563 \\
\hline 5 & $5.003 \pm 0.019$ & 0.723 & $5.072 \pm 0.036$ & 1.360 \\
\hline $\mathrm{PH}$ & & & & 1.309 \\
\hline 5 & $4.951 \pm 0.002$ & 0.663 & $4.969 \pm 0.005$ & 1.801 \\
\hline 15 & $15.010 \pm 0.008$ & 0.826 & $15.187 \pm 0.019$ & 1.375 \\
\hline 25 & $24.787 \pm 0.019$ & 1.170 & $24.817 \pm 0.022$ & \\
\hline $\mathrm{n}=3$ concentration/3 replicates, SD: Standard deviation, RSD \%: Relative standard \\
deviation
\end{tabular}

slope of the calibration curve according to $\mathrm{ICH}$ guidelines. $\mathrm{LOD}$ and LOQ for CLO were found as $0.055 \mu \mathrm{g} / \mathrm{mL}$ and $0.169 \mu \mathrm{g} /$ $\mathrm{mL}$, and $0.033 \mu \mathrm{g} / \mathrm{mL}$ and $0.102 \mu \mathrm{g} / \mathrm{mL}$ for $\mathrm{PH}$, respectively, as tabulated in Table 1.

\section{Precision}

The intraday and interday precision were determined by the analysis of three different concentrations of CLO and $\mathrm{PH}$, within the linearity range, through three replicate analyses of three pure samples of both drugs on a single day and on three consecutive days, respectively. As indicated in Table 2, data showed RSD \% less than $2 \%$. The precision of the method was considered acceptable based on its intended use.

\section{Accuracy}

Recovery study by spiking the standard at 3 concentration levels, 50,100 and $150 \%$ showed RSD \% of less than $2 \%$ with acceptable percent recovery, indicating that the proposed method was accurate and could be applicable for routine analysis of formulation (Table 3 ).

\section{Robustness}

The method remained unaffected by deliberate small changes in parameters such as wavelength $( \pm 1 \mathrm{~nm})$ and model of UV spectrophotometer. The tabulated values indicate that the method was robust in terms of changed wavelength and model of UV spectrophotometer. The data are presented in Table 4.

\section{Analysis of marketed dosage form}

The proposed method was applied to the assay of commercially available tablets containing CLO $(0.5 \mathrm{mg})$ and $\mathrm{PH}(12.5 \mathrm{mg})$. The percentage potency in the commercial formulations was found as $100.45 \%$ for CLO and $99.38 \%$ for $\mathrm{PH}$ using the proposed method. The RSD \% for the formulations was less than 2 for both drugs, as shown in Table 5. The percentage recoveries of the amount of CLO and PH in tablet dose form, expressed as a percentage assay, were in good agreement with the label claims, thereby suggesting that there was no interference from any of the excipients that normally present in tablets.

Table 3. Recovery study for CLO and PH by proposed method

\begin{tabular}{|c|c|c|c|c|c|c|}
\hline Drugs & Taken $(\mu \mathrm{g} / \mathrm{mL})$ & Level \% & $\begin{array}{l}\text { Amount of standard } \\
\text { added }(\mu \mathrm{g} / \mathrm{mL})\end{array}$ & $\begin{array}{l}\text { Total amount of drug found } \\
(\mu \mathrm{g} / \mathrm{mL})\end{array}$ & Recovery \pm SD \% & RSD \% \\
\hline \multirow{3}{*}{ CLO } & \multirow{3}{*}{2} & $50 \%$ & 1 & 3.024 & $101.21 \pm 0.015$ & 0.015 \\
\hline & & $100 \%$ & 2 & 4.007 & $100.90 \pm 0.026$ & 0.025 \\
\hline & & $150 \%$ & 3 & 5.029 & $100.84 \pm 0.034$ & 0.034 \\
\hline \multirow{3}{*}{$\mathrm{PH}$} & \multirow{3}{*}{10} & $50 \%$ & 5 & 15.118 & $101.20 \pm 0.071$ & 0.070 \\
\hline & & $100 \%$ & 10 & 20.267 & $100.15 \pm 0.211$ & 0.211 \\
\hline & & $150 \%$ & 15 & 25.244 & $100.78 \pm 0.232$ & 0.232 \\
\hline
\end{tabular}

$\mathrm{n}=3$ concentration/3 replicates, SD: Standard deviation, RSD \%: Relative standard deviation 
Table 4. Robustness of proposed method

\begin{tabular}{llll} 
Sr. No & Variable parameters & Amount of drug found \pm SD & RSD \% \\
\hline CLO & & & \\
\hline 1 & Equipment 1 UV Spectrophotometer model-UV-1700 & $5.051 \pm 0.0358$ & 1.354 \\
\hline & Equipment 2 UV Spectrophotometer model-UV-1800 & $5.029 \pm 0.0356$ & 1.348 \\
\hline 2 & Wavelength 513.79 nm & $4.906 \pm 0.0289$ & 1.315 \\
\hline & Wavelength 511.79 nm & $4.762 \pm 0.0280$ & 1.276 \\
\hline PH & Equipment 1 UV Spectrophotometer model-UV-1700 & & \\
\hline 1 & Equipment 2 UV Spectrophotometer model-UV-1800 & $4.621 \pm 0.001$ & \\
\hline & Wavelength 335.00 nm & $4.951 \pm 0.002$ & \\
\hline 2 & Wavelength 337.00 nm & $4.321 \pm 0.004$ & 0.618 \\
\hline
\end{tabular}

SD: Standard deviation

\section{Table 5. Analysis of marketed dose form}

\begin{tabular}{lllll} 
Formulation & Drug & Label claim & Assay \pm SD \% & RSD \% \\
\hline Pari CR plus & CLO & $0.5 \mathrm{mg}$ & $100.451 \pm 0.926$ & 1.295 \\
& PH & $12.5 \mathrm{mg}$ & $99.381 \pm 0.300$ & 0.331 \\
\hline
\end{tabular}

$\mathrm{n}=3$ replicates, \% RSD: Relative standard deviation; SD: Standard deviation

\section{CONCLUSION}

In the present study, a new simple, sensitive, and time-saving first-derivative synchronous spectrofluorimetry method was developed for simultaneous estimation of CLO and $\mathrm{PH}$ in pharmaceutical dose forms. First-derivative synchronous spectrofluorimetry has been found to be superior because of its highly specific spectral discrimination, readily available solvent, cost effectiveness, eco-friendly nature, and lack of extraction procedure. This spectrofluorimetry method has been found to have several advantages such as simple spectra, high selectivity, and low interference. By virtue of its high sensitivity, this method can be applied to the analysis of both CLO and $\mathrm{PH}$ in their co-formulated dose forms.

\section{ACKNOWLEDGEMENT}

The authors are thankful to Vital Formulation, Anand and Torrent Pharmaceutical, and Ahmedabad for providing gift samples of CLO and $\mathrm{PH}$, respectively. The authors are thankful to the management of Anand Pharmacy College for providing facilities for this research work.

Conflict of Interest: No conflict of interest was declared by the authors.

\section{REFERENCES}

1. Rang HP, Dale M, Ritter JM, Flower RJ. Rang and Dale's Pharmacology. $6^{\text {th }}$ ed. Churchill Livingstone Elsevier; 2007. pp. 536-542.

2. Brown JH, Taylor P, Robert LJ, Marrow JD. Goodman and Gilman's The Pharmacological Basis of Therapeutics. New York; McGraw-Hill; 2001. pp. 280.

3. Jagawat T. A Comparative Study to Assess the Efficacy and Safety of Combination Capsules of Paroxetine and Clonazepam in comparison to Paroxetine in patients suffering from Co-morbid Depression and Anxiety. Delhi Psychiatry Journal. 2011;14:106-109.
4. Romosan F, Dehelean L, lenciu M. Comorbidity of Panic Disorder with Depression: Clinical Implications. TMJ. 2003;53:246-249.

5. Indian Pharmacopoeia. Ministry of Health and Family Welfare. Indian Pharmacopoeial Commission. Ghaziabad; 2014. pp. 1434, 2439.

6. United States Pharmacopeia 38, National Formulary 33, The United States Pharmacopoeial Convention, 2888, 4765, Rockville, vol. 2, 2015.

7. British Pharmacopoeia, Medicines and Health Care Products Regulatory Agency, pp. 506-508, 587-588, London, vol. 1-2, 2014.

8. Boda JM, Bhalodiya HA, Patel PB. UV spectroscopic method for simultaneous estimation of clonazepam and Paroxetine hydrochloride hemihydrate in combined pharmaceutical formulation. Inventi Rapid: Pharm Ana and QA, 2012.

9. Sheeja VK, Swapna AS, Eapen SC, Kumar P. Method development and validation for the simultaneous estimation of clonazepam and paroxetine in combined dosage form using colorimetry. Asian $\mathrm{J}$ of Research in Chem. 2014;7:48.

10. Yanamadala G, Praveen Srikumar PP. Determination of paroxetine hydrochloride and clonazepam in pharmaceutical dosage forms. Inter $\mathrm{J}$ of Pharm. 2014;4:448-457.

11. Reddy GS, Prasad Reddy SLN, Shiva Kumar Reddy L. Development and validation of a stability indicating liquid chromatographic method for the simultaneous estimation of paroxetine and clonazepam in bulk and its pharmaceutical formulations. Inter $\mathrm{J}$ of Pharm and Pharm Sci. 2014;6:397-402.

12. Shah P, Patel J, Patel K, Gandhi T. Development and validation of an HPTLC method for the simultaneous estimation of Clonazepam and Paroxetine hydrochloride using a DOE approach. J of Taibah Uni Sci. 2017;11:121-132.

13. Umadurai M, Nagarajan V. Development and validation of a rapid UPLC Assay method for the simultaneous estimation of paroxetine and clonazepam in tablet dosage form. Inter $\mathrm{J}$ of Chem and Pharm Sci. 2014;5:42-47.

14. Anumolu PD, Sirisha N, Haripriya A, Sathesh Babu PR, Subrahmanyam VS. First derivative synchronous spectrofluorimetric quantification of Telmisartan/AmLodipine Besylate combination in tablets. $\mathrm{J}$ of Pharm Sci. 2013;12:35-40.

15. Karim MM, Jeon CW, Lee HS, Alam SM, Lee SH, Choi JH, Jin SO, Das AK. Simultaneous determination of acetylsalicylic acid and caffeine in pharmaceutical formulation by first derivative synchronous fluorimetric method. J Fluoresc. 2006;16:713-721.

16. International Conference on Harmonization, ICH Q2 (R1): Validation of Analytical Procedures: Text and Methodology. Geneva; ICH Secretariat; 2005. 